\title{
Martin Heidegger's Anti-Semitism: Philosophy of Technology and the Media in the Light of the Black Notebooks. Implications for the Reception of Heidegger in Media and Communi- cation Studies
}

\section{Christian Fuchs}

\author{
University of Westminster: Communication and Media Research Institute (CAMRI),
} London, UK, christian.fuchs@uti.at, http://fuchs.uti.at

\begin{abstract}
:
In spring 2014, three volumes of the Schwarze Hefte (Black Notebooks), Heidegger's philosophical notebooks, were published in the German edition of his collected works. They contain notes taken in the years 1931-1941 and have resulted in public debates about the role of anti-Semitism in Heidegger's thought.

This article asks: What are and should be the implications of the publication of the Black Notebooks for the reception of Heidegger in the study, theory, and philosophy of media, communication, and technology? It discusses Theodor W. Adorno and Moishe Postone's contributions to the critical theory of anti-Semitism and applies these approaches for an analysis of Heidegger's Black Notebooks. The analysis shows that the logic of modern technology plays an important role in the Black Notebooks. The paper therefore also re-visits some of Heidegger's writings on technology in light of the Black Notebooks. There is a logical link between the Black Notebooks' anti-Semitism and the analysis of technology in Being and Time and The Question Concerning Technology. The first publication provides the missing link and grounding for the second and the third.

Heidegger's works have had significant influence on studies of the media, communication, and the Internet. Given the anti-Semitism in the Black Notebooks and their implications, it is time that Heideggerians abandon Heidegger, and instead focus on alternative traditions of thought. It is now also the moment where scholars should consider stopping to eulogise and reference Heidegger when theorising and analysing the media, communication, culture, technology, digital media, and the Internet.
\end{abstract}

Keywords: Martin Heidegger, anti-Semitism, Black Notebooks, Schwarze Hefte, philosophy of technology, media philosophy, Nazi ideology, National Socialism, media and communication studies, Nazi Germany, Nationalsozialistische Deutsche Arbeiterpartei (NSDAP).

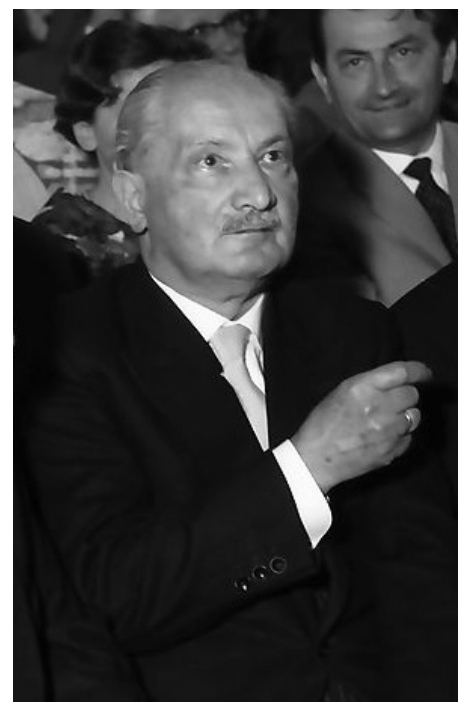

Image source:

By Willy Pragher (Landesarchiv Baden-Württenberg)

[CC BY-SA 3.0 (http://creativecommons.org/licenses/by-sa/3.0)], via Wikimedia Commons 


\section{Introduction}

In spring 2014, three volumes of the Schwarze Hefte (Black Notebooks), Heidegger's philosophical notebooks, were published in the German edition of his collected works (Heidegger 2014a, 2014b, 2014c). They contain notes taken in the years 1931-1941 and have resulted in public debates about the role of anti-Semitism in Heidegger's thought. Especially the publication of the book Heidegger und der Mythos der jüdischen Weltverschwörung (Heidegger and the Myth of Jewish World Conspiracy) by Peter Trawny (2014), who edited the Black Notebooks, has encouraged this public debate. Most people agree that such public debates about the role of Nazi ideology and anti-Semitism in Heidegger's thought are of crucial importance. They are not just discussions about Heidegger, but at the same time debates about philosophical, ideological, and political thought in Nazi Germany and its legacy. In the spirit of such debates, this article asks: What are and should be the implications of the publication of the Black Notebooks for the reception of Heidegger in the study, theory, and philosophy of media, communication, and technology? In the introductory section, I give a brief overview of some of the previous debates about Heidegger and National Socialism. Section 2 introduces Theodor W. Adorno and Moishe Postone's contributions to the critical theory of anti-Semitism that are applied in section 3 to passages in Heidegger's Black Notebooks that mention Jews. The analysis will show that the logic of modern technology plays an important role in the Black Notebooks. Section 4 therefore re-visits some of Heidegger's writings on technology in light of the Black Notebooks. In section 5, I draw some conclusions about what proper reactions to the publication of the Black Notebooks could be in the interdisciplinary field of media and communication studies.

One of the first works focusing on Heidegger and Nazism was Karl Löwith's article The Political Implications of Heidegger's Existentialism (1946). Löwith, one of Heidegger's students, argues in this paper that there is an inherent connection between Heidegger's philosophy and Nazi ideology. Victor Farías (1989) focuses in his book Heidegger and Nazism on Heidegger's early career and his role as the University of Freiburg's vice-chancellor. Tom Rockmore (1997) in his book On Heidegger's Nazism and Philosophy discusses Heidegger's rectoral address, the Beiträge zur Philosophie (1936-1938), and the works on Nietzsche and Hölderlin. He also discusses in one chapter the connection of Nazism and technology in Heidegger's works. Emmanuel Faye's book (2009) Heidegger: The Introduction of Nazism into Philosophy predominantly focuses on Heidegger's writings, speeches, lectures, and seminars during the Nazi time. Tom Rockmore (2009) argues that Farías and Faye's books both grounded important phases in the discussion of Heidegger and Nazism.

Victor Farías (1989) concludes that "Heidegger always remained faithful to a whole spate of doctrines characteristic of National Socialism" (7), which would be evidenced by "his radically discriminatory attitude regarding the intellectual superiority of the Germans, rooted in their language and their destiny; in his belief in the primacy of his own thought, much like Hölderlin's, taken as a paradigm and guide for the spiritual development of humanity itself; in his radical opposition to any form of democracy" (7-8).

Tom Rockmore $(1997,5)$ argues that "Heidegger's philosophical thought and his Nazism are interdependent and cannot be separated", "that he turned to National Socialism on the basis of his philosophy and that his later evolution is largely determined by his continuing concern with Nazism". In Heidegger's works, one finds according to Rockmore $(1997,9)$ a "constant presence of a metaphysical commitment to the German Volk as a central historical goal in his thought, a commitment which, like the theme of a fugue, is consistently renewed at regular intervals beginning in 1933. It is, I believe, this concern-in conjunction with Heidegger's underlying interest in Being-which drew him to National Socialism. This concern remains constant throughout his career and determines the later development of his position, the evolution of which cannot otherwise be grasped".

Tom Rockmore writes: "I am convinced that Heidegger's theory reflects a variety of contemporary influences, some of which he may not have been fully aware of, such as the role of a conservative, nationalistic form of Roman Catholicism in southwestern Germany in his youth, stressed by Ott, Farias, and most recently Thomä; the widespread concern, which he 
seems to have shared, for Germany, the defeated party in the First World War, to recover as a nation and to assume what many thought was the manifest German destiny; the reintroduction of destiny as an explanatory factor of historical change by Spengler; the interest in the concept of the Volk as it was developed in nineteenth-century Germany; and Heidegger's own desire to assume an ever-greater role in the German university system as the central thinker of his day, even to reform the university system according to his own view of higher education. These and other factors are ingredient in Heidegger's theory" (Rockmore 1997, 8).

Emmanuel Faye is the author who expresses most forcefully the idea that Heidegger's philosophy is Nazi ideology. "By its very content, it disseminates within philosophy the explicit and remorseless legitimation of the guiding principles of the Nazi movement" (Faye 2009, 246). "With the work of Heidegger, it is the principles of Hitlerism and Nazism that have been introduced into the philosophy libraries of the planet. [...] In order to preserve the future of philosophical thought, it is equally indispensable for us to inquire into the true nature of Heidegger's Gesamtausgabe, a collection of texts containing principles that are racist, eugenic, and radically deleterious to the existence of human reason. Such a work cannot continue to be placed in the philosophy section of libraries; its place is rather in the historical archives of Nazism and Hitlerism" (Faye 2009, 318-319).

Some reviews of the book, such as the one in the German newspaper Die Zeit, remark that Faye's arguments are too speculative and indirect, when he for example speculates that Heidegger may have written a speech for Hitler or argues that Heidegger is guilty by association because some of his formulations would sound similar to the ones made by Nazi ideologues (Meyer 2005). Faye (2005) responded to such criticism with quotes from Heidegger's works, such as from his lectures in the years 1933/1934, where Heidegger had said for example:

- „Wenn heute der Führer immer wieder spricht von der Umerziehung zur nationalsozialistischen Weltanschauung, heißt das nicht: irgendwelche Schlagworte beibringen, sondern einen Gesamtwandel hervorbringen, einen Weltentwurf aus dessen Grund heraus er das ganze Volk erzieht. Der Nationalsozialismus ist nicht irgendwelche Lehre, sondern der Wandel von Grund aus der deutschen und, wie wir glauben, auch der europäischen Welt" (Heidegger 2001, 225).

My translation: "When the Führer speaks continually of the re-education in the direction of the National Socialist Weltanschauung, then this does not mean to inculcate some slogans, but rather to bring about a total change, a plan of the world (Weltentwurf) out of whose ground he educates the entire people. National Socialism is not any doctrine, but rather the fundamental transformation of the German and, as we think, also the European world" (Heidegger 2001, 225)

- „Der Feind kann in der innersten Wurzel des Daseins eines Volkes sich festgesetzt haben und dessen eigenem Wesen sich entgegenstellen und zuwiderhandeln. Um so schärfer und härter und schwerer ist der Kampf, denn dieser besteht ja nur zum geringsten Teil im Gegeneinanderschlagen; oft weit schwieriger und langwieriger ist es, den Feind als solchen zu erspähen, ihn zur Entfaltung zu bringen, ihm gegenüber sich nichts vorzumachen, sich angriffsfertig zu halten, die ständige Bereitschaft zu pflegen und zu steigern und den Angriff auf weite Sicht mit dem Ziel der völligen Vernichtung anzusetzen" (Heidegger 2001, 91).

Translation: "The enemy may have grafted himself onto the innermost root of the existence [Dasein] of a people, and oppose the latter's ownmost essence, acting contrary to it. All the keener and harsher and more difficult it is than the struggle, for only a very small part of the struggle consists in mutual blows; it is often much harder and more exhausting to seek out the enemy as such, and to lead him to reveal himself, to avoid nurturing illusions about him, to remain ready to attack, to cultivate and increase constant preparedness and to initiate the attack on a long-term basis, with the goal of total extermination" (Faye 2009, 168). 
On October 2, 1929, Heidegger wrote in a letter to Viktor Schwoerer that either "we restore genuine forces and educators emanating from the native soil to our German spiritual life, or we abandon it definitely to the growing Jewification (Verjudung)" (cited in: Faye 2009, 34; see also Sieg 1989). Richard Hönigswald, who came from a Jewish family, was professor of philosophy at the University of Munich. He lost his professorship in September 1933 as a consequence of Nazi legislation passed in April of the same year that banned Jews from universities and other public services (Gesetz zur Wiederherstellung des Berufsbeamtentums = Law for the Restoration the Professional Civil Service). The Bavarian Ministry of Culture asked Heidegger to comment on Hönigswald's works. Heidegger in a letter responded that he considered "the appointment of this man to the University of Munich to be a scandal, the only explanation for which is the fact that the Catholic system prefers such individuals who are apparently indifferent to any vision of the world, because they are without danger to its own efforts and because they are, in a well-known sense, 'objective-liberal'. [...] Heil Hitler!" (cited in: Faye 2009, 37).

In a lecture from 1935 that after its republication in 1953 resulted in public debates, Heidegger $(2000,213)$ spoke in the context of National Socialism of the "inner truth and greatness of this movement (namely the encounter between global technology and modern man)"1. Jürgen Habermas $(1953,197)$ drew the German public's attention to his discovery that Heidegger in 1953 "publishes his words, in the meantime eighteen years old, about the greatness and inner truth of National Socialism" and that it was therefore "time to think with Heidegger against Heidegger". Christian E. Lewalter, a journalist writing for Die Zeit, as well as Heidegger himself argued that "movement" referred to the passage in parenthesis (Wolin 1993, 187-188). Other people however said that the original did not contain the parenthesised passage (see: Wolin 1993, 188; Pöggeler 1987, 276-278). The original manuscript page containing this passage is missing in Heidegger's estate of works (Heidegger 1983, 234). Petra Jaeger, the editor of some of the volumes of Heidegger's collected works, writes in the postface to the volume that contains this lecture that she has a grounded suspicion (based on a proof sheet from 1953) that Heidegger inserted the parenthesised passage to the 1953 correction (Heidegger 1983, 233-234). Silvio Vietta $(1989,31)$ has tried to argue that this passage is anti-fascist by claiming that Heidegger by "greatness" means the monstrosity of instrumental reason, "the domination by calculating reason itself" ${ }^{2}$ (translation from German). However, we today know from the Black Notebooks that Heidegger tended to see calculating reason as Jewish, which shows the absurdity of Vietta's argument.

In a letter to Herbert Marcuse, Heidegger wrote in January 1948 that Marcuse's previous letter, in which he had inquired why Heidegger did not denounce the Nazis publicly, "shows me precisely how difficult it is to converse with persons who have not been living in Germany since 1933 and who judge the beginning of the National Socialist movement from its end" (Wolin 1993, 162) and that there was not just a "regime that murdered millions of Jews", but also one that murdered millions of "East Germans" (Wolin 1993, 163). Marcuse, who coming from a Jewish family and being a Marxist had to flee from Nazi Germany, answered in May 1948 that Heidegger tried "to relativize [...] a crime by saying that other would have done the same thing. Even further: how is it possible to equate the torture, the maiming, and the annihilations of millions of men with the forcible relocation of population groups who suffered none of these outrages" (Wolin 1993, 164).

Thousands of pages have been written about Heidegger and Nazi ideology. My short introduction to this issue will suffice to give readers unfamiliar with the issue some basic ideas about this controversy. Of course much more could be said about it. To better contextualise the quotes about Jews that can be found in the Black Notebooks, I next want to discuss Theodor W. Adorno's and Moishe Postone's contributions to the critical theory of anti-Semitism.

\footnotetext{
${ }^{1}$ German original: „Was heute vollends als Philosophie des Nationalsozialismus herumgeboten wird, aber mit der inneren Wahrheit und Größe dieser Bewegung (nämlich mit der Begegnung der planetarisch bestimmten Technik und des neuzeitlichen Menschen) nicht das Geringste zu tun hat, das macht seine Fischzüge in diesen trüben Gewässern der ,Werte' und der ,Ganzheiten'“ (Heidegger 1983, 208).

${ }^{2}$ German original: „die Herrschaft des rechnenden Denkens selbst“.
} 


\section{The Critical Theory of Anti-Semitism}

Theodor W. Adorno (2002) identifies seven elements of anti-Semitism:

- I Jews are considered to be a race:

"For the fascists the Jews are not a minority but the antirace, the negative principle as such; on their extermination the world's happiness depends" (137).

- II Jews are said to be greedy, oriented on monetary interests and power, and to be representatives of financial capital:

"The fantasy of the conspiracy of lascivious Jewish bankers who finance Bolshevism is a sign of innate powerlessness, the good life an emblem of happiness. These are joined by the image of the intellectual, who appears to enjoy in thought what the others deny themselves and is spared the sweat of toil and bodily strength. The banker and the intellectual, money and mind, the exponents of circulation, are the disowned wishful image of those mutilated by power, an image which power uses to perpetuate itself" (141).

- III Jews are in a fetishist manner blamed for the abstract problems of capitalism: "Bourgeois anti-Semitism has a specific economic purpose: to conceal domination in production" (142).

"The productive work of the capitalist, whether he justified his profit as the reward of enterprise, as under liberalism, or as the director's salary, as today, was the ideology which concealed the nature of the labor contract and the rapacity of the economic system in general. That is why people shout: 'Stop thief!'-and point at the Jew. He is indeed the scapegoat, not only for individual maneuvers and machinations but in the wider sense that the economic injustice of the whole class is attributed to him" (142).

"That the circulation sphere is responsible for exploitation is a socially necessary illusion. The Jews had not been the only people active in the circulation sphere. But they had been locked up in it too long not to reflect in their makeup something of the hatred so long directed at that sphere. Unlike their Aryan colleagues, they were largely denied access to the source of added value" (143)

- IV There is hatred against Jewish religious beliefs:

"To accuse the Jews of being obdurate unbelievers is no longer enough to incite the masses. But the religious hostility which motivated the persecution of the Jews for two millennia is far from completely extinguished. [...] The others, who repressed that knowledge and with bad conscience convinced themselves of Christianity as a secure possession, were obliged to confirm their eternal salvation by the worldly ruin of those who refused to make the murky sacrifice of reason. That is the religious origin of anti-Semitism. The adherents of the religion of the Son hated the supporters of the religion of the Father as one hates those who know better. This is the hostility of spirit hardened as faith in salvation for spirit as mind" $(144,147)$.

- $V$ The imitation of asserted natural characteristics of Jews is a psychological expression of the human domination of nature and humans and an imitation of magic practices:

"There is no anti-Semite who does not feel an instinctive urge to ape what he rakes to be Jewishness. The same mimetic codes are constantly used: the argumentative jerking of the hands, the singing tone of voice, which vividly animates a situation or a feeling independently of judgment, and the nose, that physiognomic principium individuationis, which writes the individual's peculiarity on his face. In the ambiguous partialities of the sense of smell the old nostalgia for what is lower lives on, the longing for immediate union with surrounding nature, with earth and slime" (151). "The purpose of the fascist cult of formulae, the ritualized discipline, the uniforms, and the whole allegedly irrational apparatus, is to make possible mimetic behavior. The elaborate symbols proper to every counterrevolutionary movement, the death's heads and masquerades, the barbaric drumming, the monotonous repetition of words and gestures, are so many organized imitations of magical practices, the mimesis of mimesis" (152). "The Jews as a whole are charged with practic- 
ing forbidden magic and bloody rituals. [...] They are pronounced guilty of what, as the first citizens, they were the first to subdue in themselves: the susceptibility to the lure of base instincts, the urge toward the beast and the earth, the worship of images. Because they invented the concept of the kosher, they are persecuted as swine. The anti-Semites appoint themselves executors of the Old Testament: they see to it that the Jews, having eaten of the Tree of Knowledge, unto dust shall return" (153).

- VI Features of a subject, such as domination within society, are projected onto Jews as an object. They are based on this logic said to be e.g. especially powerful:

"Anti-Semitism is based on false projection. [...] Impulses which are not acknowledged by the subject and yet are his, are attributed to the object: the prospective victim. [...] Those impelled by blind murderous lust have always seen in the victim the pursuer who has driven them to desperate self-defense" (154). "Instead of the voice of conscience, it [the subject of anti-Semitism] hears voices; instead of inwardly examining itself in order to draw up a protocol of its own lust for power, it attributes to others the Protocol of the Elders of Zion" (156). "No matter what the makeup of the Jews may be in reality, their image, that of the defeated, has characteristics which must make totalitarian rule their mortal enemy: happiness without power, reward without work, a homeland without frontiers, religion without myth" (164-165).

- VII Anti-Semitism is based on pure irrational stereotypes, blanket generalisations and judgments, the most radical form of instrumental reason, ticket thinking that labels individuals as belonging to groups that should be annihilated, and hatred against Otherness: "Anti-Semitic views always reflected stereotyped thinking. Today only that thinking is left. People still vote, but only between totalities" (166). "Judgment is no longer based on a real act of synthesis but on blind subsumption" (166-167).

"It is not just the anti-Semitic ticket which is anti-Semitic, bur the ticket mentality itself. The rage against difference which is teleologically inherent in that mentality as the rancor of the dominated subjects of the domination of nature is always ready to attack the natural minority, even though it is the social minority which those subjects primarily threaten (172).

"The disregard for the subject makes things easy for the administration. Ethnic groups are transported to different latitudes; Individuals labeled 'Jew' are dispatched to the gas chambers" (167).

"It has been shown, in fact, that anti-Semitism's prospects are no less good in 'Jew-free' areas than in Hollywood itself. Experience is replaced by cliche, the imagination active in experience by diligent acceptance" (166).

"The more superfluous physical labor is made by the development of technology, the more enthusiastically it is set up as a model for mental work, which must not be tempted, however, to draw any awkward conclusions. That is the secret of advancing stupidity, on which anti-Semitism thrives" (167).

The political theorist and historian Moishe Postone grounds a critical theory of anti-Semitism and ideology in Marx's critique of commodity fetishism and points out the inherent connection of anti-Semitism and capitalism. Capitalism is grounded in an antagonism between the commodity's value and exchange-value on the one side and value and use-value on the other side. Postone says that in capitalism, value is "abstract, general, homogeneous", whereas use-value is "concrete, particular, material" (Postone 2003, 90). The commodity logic fetishises the concrete and veils the value as abstract social relation that underlies the commodity. In commodity fetishism, the abstract dimension appears as natural and endless, the concrete dimension as thing without social relations (Postone 2003, 91).

Postone $(1980,109)$ argues that in the value form, capitalism's "dialectical tension between value and use-value" is doubled in the appearance of money as abstract and the commodity as concrete. Capitalism requires for its existence both money and commodities, value and use-value, abstract and concrete labour. Money mediates commodity-exchange, so money cannot exist without the logic of commodities. Commodities are made for being exchanged. Money is the general equivalent of this exchange of commodities. So commodi- 
ties cannot exist without exchange-value and a general equivalent. Another way of expressing the dialectic of commodity and money is to say that the sphere of commodity production exists in relation to the sphere of circulation and vice-versa. Commodity fetishism is a form of appearance in which the abstract sociality of commodities is split-off from its concreteness: only the immediate concrete (the good one consumes, the money one holds in the hand) is taken as reality. This immediate concrete obscures the existence of the more abstract, not directly visible social relations behind the immediate phenomena.

Postone says that in the anti-Semitic ideology, the dual character of the commodity of use-value and value is "doubled' in the form of money (the manifest form of value) and of the commodity (the manifest form of use-value). Although the commodity as a social form embodies both value and use-value, the effect of this externalization is that the commodity appears only as its use-value dimension, as purely material. Money, on the other hand, appears as the sole repository of value, as the source and locus of the purely abstract, rather than as the externalized manifest form of the value dimension of the commodity form itself" (Postone 2003, 91).

Postone argues that modern anti-Semitism is a biologisation and naturalisation of the commodity fetish. It would be based on the "notion that the concrete is 'natural"' and that the "natural" is "more 'essential' and closer to origins" (Postone 1980, 111). "Industrial capital then appears as the linear descendent of 'natural' artisanal labor", "industrial production" appears as "a purely material, creative process" (Postone 1980, 110). Ideology separates industrial capital and industrial labour from the sphere of circulation, exchange and money that is seen as "parasitic" (Postone 1980, 110). In Nazi ideology, the "manifest abstract dimension is also biologized-as the Jews. The opposition of the concrete material and the abstract becomes the racial opposition of the Arians and the Jews" (Postone 1980, 112). Modern antiSemitism is a one-sided "critique" of capitalism that sees the sphere of circulation as totality of capitalism, biologistically inscribes Jewishness into circulation and into capitalism, and excludes technology and industry - that are perceived as being productive and Aryan-from capitalism. In Nazi ideology, capitalism "appeared to be only its manifest abstract dimension, which was in turn held responsible for the economic social, and cultural changes associated with the rapid development of modern industrial capitalism" (Postone 2003, 93)

Anti-Semitism identifies the negative changes, dislocations and deterritorialisations associated with capitalism, such as urbanisation, proletarianisation, individualisation, technification, and detraditionalisation, with the abstract side of capitalism that is perceived as the powerful universality of capitalism, socialism or some other phenomenon. "Capitalism appeared to be only in its manifest abstract dimension which, in turn, was responsible for the whole range of concrete social and cultural changes associated with the rapid development of modern industrial capitalism" (Postone 1980, 112).

\section{The Black Notebooks}

In Heidegger's Schwarze Hefte (Black Notebooks) one can find passages, where he talks about Jews.

- „Die zeitweilige Machtsteigerung des Judentums aber hat darin ihren Grund, daß die Metaphysik des Abendlandes, zumal in ihrer neuzeitlichen Entfaltung, die Ansatzstelle bot für das Sichbreitmachen einer sonst leeren Rationalität und Rechenfähigkeit, die sich auf solchem Wege eine Unterkunft im ,Geist' verschaffte, ohne die verborgenen Entscheidungsbezirke von sich aus je fassen zu können. Je ursprünglicher und anfänglicher die künftigen Entscheidungen und Fragen werden, um so unzugänglicher bleiben sie dieser ,Rasse“"' (Heidegger 2014c, 46 [XII, 67-68]).

"Jewry's temporary increase in power is, however, grounded in the fact that Western metaphysics, especially in its modern development, furnishes the starting point for the diffusion of a generally empty rationality and calculative ability, which in this way provides a refuge in 'spirit', without being able grasp the hidden decision regions on their own. The 
more originary and primordial the prospective decisions and questions, the more they remain inaccessible to this 'race"'3.

- (b) „Die Juden ,leben“ bei ihrer betont rechnerischen Begabung am längsten schon nach dem Rasseprinzip, weshalb sie sich auch am heftigsten gegen die uneingeschränkte Anwendung zur Wehr setzen. Die Einrichtung der rassischen Aufzucht entstammt nicht dem ,Leben' selbst, sondern der Übermächtigung des Lebens durch die Machenschaft. Was diese mit solcher Planung betreibt, ist eine vollständige Entrassung der Völker durch die Einspannung derselben in die gleichgebaute und gleichschnittige Einrichtung alles Seienden. Mit der Entrassung geht eine Selbstentfremdung der Völker in eines - der Verlust der Geschichte - d.h. der Entscheidungsbezirke zum Seyn" (Heidegger 2014c, 56 [XII, 8283]).

"The Jews 'live' by their marked talent for calculation second only to the principle of race, which is why they are resisting its consistent application with utmost violence. The establishment [Einrichtung] of racial breeding [eugenics] does not stem from 'life' itself, but from the overpowering of life through machination [technology]. What they push forward with such a plan is the complete deracialization of all peoples by clamping them into a uniformly constructed and tailored establishment [Einrichtung] of all beings. At one with deracialization is the self-alienation of peoples - the loss of history - i.e., the decision regions of Be-ing".

- (c) „Auch der Gedanke einer Verständigung mit England im Sinne einer Verteilung der ,Gerechtsamen' der Imperialismen trifft nicht ins Wesen der geschichtlichen Vorgangs, den England jetzt innerhalb des Amerikanismus und des Bolschewismus und d. h. zugleich auch des Weltjudentums zu Ende spielt. Die Frage nach der Rolle des Weltjudentums ist keine rassische, sondern die metaphysische Frage nach der Art von Menschentümlichkeit, die schlechthin ungebunden die Entwurzelung alles Seienden aus dem Sein als weltgeschichtliche ,Aufgabe' übernehmen kann" (Heidegger 2014c, 243 [XIV, 121]). "The idea of an understanding with England in terms of a distribution of imperialist "prerogatives' misses the essence of the historical process, in which England plays along with Americanism and Bolshevism and at the same time world Jewry to an end. The question of the role of world Jewry is not racial, but the metaphysical question of the type of humanity that can accept from Being the world-historical 'task' of uprooting all beings".

- (d) „Das Weltjudentum, aufgestachelt durch die aus Deutschland herausgelassenen Emigranten, ist überall unfaßbar und braucht sich bei aller Machtentfaltung nirgends an kriegerischen Handlungen zu beteiligen, wogegen uns nur bleibt, das beste Blut der Besten des eigenen Volkes zu opfern" (Heidegger 2014c, 262 [XV, 17]).

"World Jewry, spurred on by emigrants allowed to leave Germany, is pervasive and impalpable, using all its powers to avoid participating in military actions, whereas all that remains to us is to sacrifice the best blood of the best of our own people".

Peter Trawny $(2014,11)$ argues in his book Heidegger und der Mythos der jüdischen Weltverschwörung (Heidegger and the Myth of Jewish World Conspiracy) that such quotes are characteristic for Heidegger's onto-historical anti-Semitism (seinsgeschichtlicher Antisemitismus). The question arises how one can interpret these passages with the help of Adorno's elements of anti-Semitism. Heidegger advised the Black Notebooks should be published as the final part of his Collected Works (see: Heidegger 2014c, 279), which may be an indication that they have a special role, constitute his legacy (Trawny 2014, 12), or the ground of his thought.

Richard Wolin (2014), who had expressed scepticism about Emmanuel Faye's (2009) book Heidegger: The Introduction of Nazism into Philosophy (see Cohen 2009), argued after the publication of the Black Notebooks: "Heidegger's philosophical partisanship for National Socialism was not a series of contingent errors or odd misjudgements. It was a betrayal of philosophy, of reasoning and thinking, in the most profound sense. [...] Given the disturbing

\footnotetext{
${ }^{3}$ Source of this and the following translations from the Black Notebooks: http://www.countercurrents.com/2014/03/heidegger-on-world-jewry-in-the-black-notebooks/
} 
revelations contained in the Black Notebooks, any discussion of Heidegger's legacy that downplays or diminishes the extent of his political folly stands guilty, by extension, of perpetuating the philosophical betrayal initiated by the Master himself".

Tom Rockmore, author of On Heidegger's Nazism and Philosophy (Rockmore 1997), welcomes Trawny's book, but somewhat disagrees with its conclusions: Trawny "thinks Heidegger had a kind of private anti-Semitism, which was only revealed in the second half of the 1930s in his seinsgeschichtlicher Antisemitismus [onto-historical anti-Semitism], whereas I think that the anti-Semitism was there all the time and was visible for anyone who wanted to look" (Rockmore 2014).

I want to now relate the quotes from the Black Notebooks to Adorno's elements of antiSemitism.

In quote (a), Heidegger sees Jews as a powerful group, which plays with the myth of a Jewish world conspiracy (VI). He furthermore argues that this group has a specific quality, namely a calculative rationality that is grounded in Western metaphysics. He does not argue that this is a biological characteristic, but a socio-natural one, i.e. he constructs "the Jews" as a homogenous collective (VII), attributes to them and blames them for qualities of capitalism (III). The identification of Jews with instrumental rationality has a double feature: Instrumental rationality on the one hand is an expression of the drive to accumulate capital and power and on the other hand the operating principle of modern technology. Heidegger blames Jews both for the logic of capitalism and industrialism (II, VII).

Quote (b) implies that Heidegger blames Jews for what he calls "deracialisation" (Entrassung). He accuses them here for impurifying blood that he considers pure and original. They would however oppose the application of the principle of race to themselves. What can he mean when he speaks of such an application? The Nazis introduced in 1935 the Nuremberg Racial Laws that classified people with three or four Jewish grandparents as "Jews", those with one or two Jewish grandparents as "crossbreed" (Mischling), and those without Jewish grandparents as "Aryans". The preface to the law said that it is "pervaded by the insight that the purity of German blood is the precondition for the survival of the German people" and "ensouled by the unfaltering will to protect the German nation for all future" ${ }^{4}$. It prohibited sex and marriage between what it considered to be Aryans and non-Aryans. Heidegger in this passage seems to allude to these Laws and blame Jews for their own persecution by the Nazis. Heidegger here makes a racist argument (I) that constructs Jews as a general collective (VII) to whom he ascribed biological features (I). He blames the victims for their oppression (VI). Jürgen Habermas $(1983,184)$ stresses in a different context that Heidegger after 1945 did not publicly condemn the Nazis and his role in the Nazi regime, but blamed the victims. The principle of race would be the consequence of machinations, a concept by which Heidegger means modern technology (Trawny 2014, 22, 34). So Heidegger blames Jews both for the negative features of modern technology as well as for their racist oppression. Heidegger $(1989,1999)$ also uses the notion of machination (Machenschaften) in his Beiträge zur Philosophie (Contributions to Philosophie, 1936-1938), where he says that the "dominance of reason as equalization of all people is merely the consequence of Christianity and Christianity is fundamentally of Jewish origin"5 (Heidegger 1999, 38).

In quote (c), Heidegger uses the term "world Jewry" (Weltjudentum), which constructs Jews as a homogenous collective (VII) that rules the world (VI). It would not be a biological, but a social and political feature of Jews that they are "uprooted", by which he means an opposition to what he sees as the German's rootedness in soil, nation, and nature. Heidegger implies that Jews are cosmopolitan and international, which he sees as negative features of modernity that destroy an original organicity that he identifies with the Germans. Heidegger here identifies Jews with modernity (VI, III) and longs for a pre-modern society that he asso-

\footnotetext{
${ }^{4}$ Translation from German: „Durchdrungen von der Erkenntnis, daß die Reinheit des deutschen Blutes die Voraussetzung für den Fortbestand des Deutschen Volkes ist, und beseelt von dem unbeugsamen Willen, die Deutsche Nation für alle Zukunft zu sichern, hat der Reichstag einstimmig das folgende Gesetz beschlossen, das hiermit verkündet wird", http://www.documentarchiv.de/ns/nbgesetze01.html, accessed on February 23, 2015.

${ }^{5}$ In German: „sofern aber die Vernunftherrschaft als Gleichsetzung aller nur die Folge des Christentums ist und dieses im Grunde jüdischen Ursprungs" (Heidegger 1989, 54)
} 
ciates with the Germans. He also alludes to traditions, mystic and magic origins that he considers to be lost because of the influence of modernity that he sees as being Jewish in character $(\mathrm{V})$.

In quote (d), Heidegger blames Jews indirectly for the war against Germany by implying that they have influence on the Allied forces (II, VI). He in a racist (I) manner argues that the Germans are victims who have to defend themselves (VI: the actual offenders are interpreted as being victims and victims blamed as being culprits). The formulation "the best blood of the best" in a racist manner assumes that the Germans are a biologically superior race (I).

Heidegger in these quotes employs six of the seven elements of anti-Semitism that Adorno identified: He sees Jews and Germans as forming two races (I), identifies Jews with modernity, capitalism, and modern technology (II, III), makes use of mystical and naturalistic logic by arguing that Jews are uprooted and threaten the Germans' rootedness (V), and describes Jews as a powerful "world Jewry" that rules the world (VI) as well as a homogenous collective to which he ascribes negative biological, social, and political characteristics (VII). The only feature of anti-Semitism that is not present is the religious element (IV), which can be explained by the circumstance that Christian religion does not play a role in Nazi ideology.

All four quotes were written in 1939-1941, which shows that Heidegger after he had stepped down as vice-chancellor of the University of Freiburg in 1934 remained a committed Nazi and anti-Semite at least until 1941. The Black Notebooks deconstruct the myth that Heidegger stepped down as vice-chancellor because he was opposed to Nazi ideology. Peter Trawny $(2014,28)$ argues that Heidegger was disappointed by the Nazi's modernism and their use of modern technology and that he had a specific version of Nazi ideology in mind that he termed "spiritual National Socialism"6 (Heidegger 2014a, 135 [Überlegungen und Winke III, §72]). This version of Nazi ideology is, as the quotes show, definitely based on anti-Semitism. In notes made in the Black Notebooks in autumn 1932, Heidegger saw Nazism as barbaric and identified this barbarity its greatness: "National Socialism is a barbaric principle. This is its essence and its possible greatness"'.

Martin Heidegger's son Hermann, who is in charge of the publication of his father's collected works, argues that the comments about Jews are only present on "a total of three out of the Black Notebook's 1250 pages" ${ }^{\text {. }}$. He says about the accusation that his father and his philosophy were anti-Semitic: "It is true that he was critical of World-Jewry, but he definitely was not an anti-Semite" 9 . The term World-Jewry (Weltjudentum) is in itself problematic because it constructs Jews as homogenous worldwide collective power. It is a dangerous argument to argue that Heidegger was no Nazi and anti-Semite because his anti-Semitic arguments are limited to some quotes. The critique of modernity and modern technology is crucial for Heidegger's work, but his critique remains in most of his works phenomenological without analysing the actual causes. The discussed quotes are so important because they show that Heidegger's critique of modernity was short-circuited and in a manner typical for anti-Semitic ideology blames Jews for phenomena that are characteristic for and have their roots in capitalism as a whole. National Socialism is, as Moishe Postone $(1980,2003)$ has shown, a short-circuited critique of capitalism that does not question capitalism as totality, but inscribes its negative features into Jews.

Strategies commonly used to defend Heidegger include attempts to argue that the "uninitiated" do not understand the full significance and meaning of his works ${ }^{10}$, that Heidegger's

\footnotetext{
${ }^{6}$ Translation from German: „Geistiger Nationalsozialismus“

7 Translation from German: „Der Nationalsozialismus ist ein barbarisches Prinzip. Das ist sein Wesentliches und seine mögliche Größe“ (Heidegger 2014a, 194 [Überlegungen und Winke III, §206]).

${ }^{8}$ Translation from German, Interview in: Junge Freiheit 40/2014, September 26, 2014.

${ }^{9}$ German original: „Es stimmt, daß er kritisch gegenüber dem Weltjudentum war, aber er war auf keinen Fall ein Antisemit”. Interview in: Junge Freiheit 40/2014, September 26, 2014.

${ }^{10}$ Rockmore $(1997,5)$ argues that this strategy takes on the form that some Heideggerians say that those who are not "able to quote chapter and verse at the drop of a manuscript" and are not "capable on demand of adducing unpublished material in support of an argument" cannot understand Heidegger. Such arguments are typical for the sectarian Heidegger cult. "Heideggerians have tended to seize on the difficulties of Heidegger's thought in order to make of its interpretation an almost mystical, hieratic process. The result, in imitation of Heidegger's own strategy, is to shield Heidegger's thought from any attempt at criticism. [...] The obvious fact that Heidegger ex-
} 
political and philosophical positions are non-overlapping (Heidegger the man and Heidegger the thinker), that Heidegger only adhered to Nazi ideology during a short period while he was the University of Freiburg's Rector in 1933/34, that he defended Jews, and that he conceptually opposed Nazism (for an overview of such arguments see: Rockmore and Margolis 1989, $\mathrm{x}$; Rockmore 1987, 3-7). Some of the books on the topic of Heidegger and Nazism, such as the ones by Farías (1989), Rockmore (1997), and Faye (2009), have deconstructed these myths. It is not unlikely that Heideggerians even after the publication of the Black Notebooks will come up with defensive arguments similar to the ones made earlier or will extend such lines of thought. They could for example argue that the anti-Semitic passages are limited to single pages, that Heidegger did not publish them during his lifetime, and that his views therefore remained private. Such arguments are now however even harder to make then before publication of the Black Notebooks. It is a fact that Heidegger himself instructed that the Black Notebooks should be published as part of his collected works' final volumes (Trawny 2014; Heidegger 2014c, 279). Given that his philosophical notes are now public knowledge and Heidegger considered their publication important, it is crucial to engage with them and to discuss their impacts and implications.

It is unlikely that Heidegger's anti-Semitism was restricted to the time of National Socialism (1933-1945). In a letter to his wife, Heidegger in 1920 wrote that villages were "flooded with Jews and racketeers" ${ }^{\prime 11}$ (Heidegger 2007, 112). The fact that Heidegger treated his Jewish students and his Jewish lover Hannah Arendt with respect, an argument that those who want to defend Heidegger tend to use, does not stand in opposition to his anti-Semitism, it rather may be characteristic for the anti-Semitic acceptance of what Hannah Arendt (1958, $56)$ in her characterisation of anti-Semitic ideology termed "exceptional Jews"12. Victor Farías $(1989,4)$ argues that when "Heidegger decided to join the National Socialist Party, he was following an already-prepared path" and that Heidegger's thoughts were "nourished in traditions of authoritarianism, anti-semitism, and ultranationalism that sanctified the homeland in its most local sense"

Theodor W. Adorno argues that Nazi ideology also is immanent in Sein und Zeit that was published in 1926 (Heidegger 1926). Adorno writes in his analysis that Heidegger's "metaphysics of death" cultivate "the heroic possibilities of death" and is "a propaganda for death" (Adorno 1965/2001, 131; see also Löwith 1946). Heidegger's combination of philosophy and poetry is for Adorno (1960/1961) "provincial kitsch" (229) that uses "archaic language" (230) [translation from German]. For Adorno, Heidegger's fetishism of the origin is a form of mysticism (Adorno 1960/1961, 32-34). The "cult of origin and renewal" would "not by accident and not externally have sympathy with the barbarism that took shape in his [Heidegger's] political history" ${ }^{\prime 3}$ so that foundations of "National-Socialist ideology" [translation from German] would be contained in Sein und Zeit (241). "Heidegger's agreement with fascism and the ideology

perts inevitably have a heavy professional investment in the importance, even the correctness, of his position explains their widespread reluctance to call it in question in any but the most timid manner" (22). "A particularly uncompromising form of this tactic consists in the denial that an outsider either does or possibly could understand the Heideggerian position. Examples include De Waehlens's assertion that Löwith, Heidegger's former student and later colleague, was not sufficiently versed in the thought of the master to criticize it, and Derrida's claim that Farías, who spent a dozen years writing a book about Heidegger's Nazism, could not possibly have spent more than an hour studying Heidegger's thought. A more general form of this tactic is to characterize whatever one says about the master thinker as metaphysics on the theory that Heidegger has somehow gone beyond it. This is tantamount to claiming that, as Ryle used to say, there is a category mistake since a metaphysical statement cannot possibly apply to Heidegger's view. The tendency to limit the Heideggerian discussion to Heidegger scholars works to preserve the Heideggerian view from prying eyes by rendering it invisible to any but the orthodox believer" (23-24).

${ }^{11}$ Translation from German: „überschwemmt von Juden u. Schiebern“.

12 "Society, confronted with political, economic, and legal equality for Jews, made it quite clear that none of its classes was prepared to grant them social equality, and that only exceptions from the Jewish people would be received. Jews who heard the strange compliment that they were exceptions, exceptional Jews, knew quite well that it was this very ambiguity - that they were Jews and yet presumably not like Jews - which opened the doors of society to them" (Arendt 1958, 56).

${ }^{13}$ Translation from German: „Es kommt indessen bei inm so zu einem Kult von Ursprung oder Erneuerung, dem die Sympathie mit der Barbarei, die in seiner politischen Geschichte sich ausgeprägt hat, nicht zufällig und nicht äußerlich ist" (240). 
of the conservative revolution, the more elegant version of fascist ideology, was not a lack of character of the philosopher, but lay in the content of his doctrine"14 (287).

Farias' (1989) interpretation of Sein und Zeit is that it contains "philosophical beliefs that foreshadow Heidegger's later convictions" (60) and that there is an "inner continuity of Heidegger's thinking between 1927 and 1933" (62). Farías $(1989,4)$ especially stresses in this context Heidegger's concepts of "'authentic' being-in-community, and his own links with the people, the hero, and the struggle $(\S 74)$ - and his rejection of democratic forms of social life, a rejection inspired by the ideas of Paul Yorck von Wartenburg and Wilhelm Dilthey $(\S 77)$ ".

For the philosophy and study of technology and the media, it is of particular importance that Heidegger in the Black Notebooks blames Jews for modern technology's instrumental reason.

\section{Heidegger, the Media, and Technology}

Peter Trawny $(2014,43)$ points out the importance of the role of technology in Heidegger's anti-Semitic thoughts: "When Heidegger regards the 'skill of calculation' as Jewish and typically modern, then all of this is altogether declared as an epiphenomenon of modern technology" (translation from German). "But the character of the technical, that which is like 'machinations', was the 'groundless' (das Bodenlose) and the 'worldlessness' (das Weltlose) that the philosopher ascribed to Jews" (Trawny 2014, 55; translation from German). Trawny $(2014,79)$ argues that Heidegger saw modern technology as the enemy of the Germans and therefore asked himself: "Was the triumph of technology not at last the victory of 'world Jewry'?" (translation from German).

Heidegger's technophobic conservative opposition to modern technology was already present in Sein und Zeit, where he introduced the concept of das Man (the they) and das Zeug (the equipment). "We shall call the beings encountered in taking care useful things [das Zeug]. In our dealings we find utensils for writing, utensils for sewing, utsensils for working, driving, measuring. We must elucidate the kind of being of useful things. This can be done following the guideline of the previous definition of what makes useful thing a useful thing: its utility [Zeughaftigkeit]"15 (Heidegger 2010, 68).

Technology for Heidegger involves a means-end-relationship: "A useful thing is essentially 'something in order to [...]'. The different kinds of 'in order to' such as serviceability, helpfulness, usability, handiness, constitute a totality of useful things. The structure of 'in order to' ['um-zu'] contains a reference [Verweisung] of something to something"16 (Heidegger 2010, $68)$. "We shall call the useful thing's kind of being in which it reveals itself by itself handiness [Zuhandenheit]"17 (Heidegger 2010, 69).

Heidegger hints at the fact that with the modernisation of society, the use of technologies was no longer limited to the household economy, but was extended to the creation of a public infrastructure: "The work taken care of in each case is not only at hand in the domestic world of the workshop, but rather in the public world. Along with the public world, the surrounding world of nature is discovered and accessible to everyone. In taking care of things,

\footnotetext{
14 Translation from German: „Heideggers Einverständnis mit dem Faschismus und der Ideologie der konservativen Revolution, der eleganteren Version der faschistischen Ideologie, war keine Gesinnungslosigkeit des Philosophen, sondern lag im Gehalt seiner Doktrin“.

15 In German: „Wir nennen das im Besorgen begegnende Seiende das Zeug. Im Umgang sind vorfindlich Schreibzeug, Nähzeug, Werk-, Fahr-, Meßzeug. Die Seinsart von Zeug ist herauszustellen. Das geschieht am Leitfaden der vorherigen Umgrenzung dessen, was ein Zeug zu Zeug macht, der Zeughaftigkeit“ (Heidegger 1926, 92).

${ }^{16}$ In German: „Zeug ist wesenhaft »etwas, um zu . . . « . Die verschiedenen Weisen des »Um-zu« wie Dienlichkeit, Beiträglichkeit, Verwendbarkeit, Handlichkeit konstituieren eine Zeugganzheit. In der Struktur »Um-zu « liegt eine Verweisung von etwas auf etwas" (Heidegger 1926, 92).

17 "Die Seinsart von Zeug, in der es sich von ihm selbst her offenbart, nennen wir die Zuhandenheit” (Heidegger 1926, 93).
} 
nature is discovered as having some definite direction on paths, streets, bridges, and buildings" ${ }^{18}$ (Heidegger 2010, 70).

There are however problems that technology faces that Heidegger terms das Unzuhandene (the unhandy) (Heidegger 1926, 98-99; Heidegger 2010, 72-73): things that are unusable, missing, obstacles, unsuited, damaged. The unhandy means "conspicuousness, obtrusiveness, and obstinacy" ${ }^{19}$ (Heidegger 2010, 73). "Unhandy things are disturbing and make evident the obstinacy of what is initially to be taken care of before anything else" 20 (Heidegger 2010, 73).

Heidegger introduces these problems and disturbances caused by technology in $\S 16$, which is soon thereafter followed by a section that discusses Descartes' rational ontology of the world that Heidegger sees as opposed to his phenomenology (§§19-21). In the chapter that follows (chapter 4), Heidegger introduces the concept of das Man (the they), a worldless form of being that, given the examples used, stands for modernity and thereby also for modern technology and modern media.

When introducing the they, Heidegger explicitly refers (besides for example public transport) to newspaper and entertainment and argues that the these media bring about massification, anonymity, manipulation, and dictatorship that alienate humans from each other, i.e. from sociality:

We have shown earlier how the public 'surrounding world' is always already at hand and taken care of in the surrounding world nearest to us. In utilizing public transportation, in the use of information services such as the newspaper, every other is like the next. This being-with-one-another dissolves one's own Da-sein completely into the kind of being of 'the others' in such a way that the others, as distinguishable and explicit, disappear more and more. In this inconspicuousness and unascertainability, the they unfolds its true dictatorship. We enjoy ourselves and have fun the way they enjoy themselves. We read, see, and judge literature and art the way they see and judge. But we also withdraw from the 'great mass' the way they withdraw, we find 'shocking' what they find shocking. The they, which is nothing definite and which all are, though not as a sum, prescribes the kind of being of everydayness ${ }^{21}$ (Heidegger 2010, 123).

It here becomes evident that Heidegger advances a conservative critique that sees modern technology as such as a problem. The problem is formulated abstractly as das Man (the they), but its causes and context remain unclear in the phenomenology that Heidegger formulated in Sein und Zeit. It is for Heidegger certainly not the capitalist use and design of and bureaucratic shaping of technology that form this context because class, the state, and capitalism are categories that are absent from the analysis. Heidegger does not argue for a redesign of modern technology and modern society, but for their abolishment. Tom Rockmore $(1997,215)$ argues that Heidegger's conservative anti-technologism was influenced by the works of Friedrich Nietzsche, Oswald Spengler, and Ernst Jünger. Were one to put "Heidegger's technological vision [...] into practice, modern life as we know it would have to be abandoned" (Rockmore 1997, 233).

\footnotetext{
${ }^{18}$ In German: „Das je besorgte Werk ist nicht nur in der häuslichen Welt der Werkstatt etwa zuhanden, sondern in der öffentlichen Welt. Mit dieser ist die Umweltnatur entdeckt und jedem zugänglich. In den Wegen, Straßen, Brücken, Gebäuden ist durch das Besorgen die Natur in bestimmter Richtung entdeckt" (Heidegger 1926, 66). ${ }^{19}$ In German: „Auffälligkeit, Aufdringlichkeit und Aufsässigkeit” (Heidegger 1926, 99).

${ }^{20}$ In German: „Dieses Unzuhandene stört und macht die Aufsässigkeit des zunächst und zuvor zu Besorgenden sichtbar" (Heidegger 1926, 99).

${ }^{21}$ Translation from German: „Früher wurde gezeigt, wie je schon in der nächsten Umwelt die öffentliche »Umwelt« zuhanden und mitbesorgt ist. In der Benutzung öffentlicher Verkehrsmittel, in der Verwendung des Nachrichtenwesens (Zeitung) ist jeder Andere wie der Andere. Dieses Miteinandersein löst das eigene Dasein völlig in die Seinsart »der Anderen « auf, so zwar, daß die Anderen in ihrer Unterschiedlichkeit und Ausdrücklichkeit noch mehr verschwinden. In dieser Unauffälligkeit und Nichtfeststellbarkeit entfaltet das Man seine eigentliche Diktatur. Wir genießen und vergnügen uns, wie man genießt; wir lesen, sehen und urteilen über Literatur und Kunst, wie man sieht und urteilt; wir ziehen uns aber auch vom »großen Haufen« zurück, wie man sich zurückzieht; wir finden »empörend «, was man empörend findet. Das Man, das kein bestimmtes ist und das Alle, obzwar nicht als Summe, sind, schreibt die Seinsart der Alltäglichkeit vor" (Heidegger 1926, 169).
} 
David J. Gunkel and Paul A. Taylor (2014) argue that the "ceaseless noise of public chitchat" is a form of das Man (41) and that this concept is of special relevance in the time of social media: "Heidegger's concept of idle talk is particularly prescient, given the advent of narrowcasting applications like Facebook and Twitter" (39). Both platforms are certainly predominantly platforms of mundane everyday information and communication, a lot of which is advertising, entertainment, self-presentation, and reputation management transmitted at high speed, which reflects the instrumental logic of capitalism, neoliberalism, and individualism. Gunkel and Taylor do not discuss in further detail if this feature is in their view immanent in social media as such or if it has not rather to do with the capitalist design and use of these platforms that reflect the very patterns of capitalism. The second assumption also implies the potential for social media's non-capitalist use and re-design that are focused on communicative action, slow politics, political discussion, and political organisation.

For Heidegger (1929), all metaphysics is forgetful of being (Seinsvergessenheit), it equates being (Sein) with bei-ings (Seiendes), forgets and does not ask the question about the truth of being. In the postscript to his 1929 professorial inaugural lecture Was ist Metaphysik? (What is Metaphysics?) at the University of Freiburg, Heidegger argues that modern science is the dominant form of metaphysics in modern society, "a means of the calculating reification of be-ing" 22 (Heidegger 1929, 43), which shows the inherent connection that Heidegger saw between metaphysics, modern science and technology. He here again brings up the notion of calculating reason.

In 1935/1936 Heidegger held a lecture titled Basic Questions of Metaphysics that was published under the name What is a Thing? (Heidegger 1935/1936): He characterises modern science as "a factual, experimental, measuring science" whose "fundamental characteristic is the manner of working with the things and the metaphysical projection of the thingness of the things" (68). So for Heidegger, mathematics is at the core of modern science and technology and its main feature is thingification. He confirms in this lecture that he sees mathematics, technology, and science, and modern metaphysics as inherently connected: "[M]odern natural science, modern mathematics, and modern metaphysics sprang from the same root of the mathematical in the wider sense" (97).

The question What is a Thing? brings up the question of reification/thingification. It is evident in Sein und Zeit that Heidegger (1926) must have read Lukács (1923) when he asks: "But what does reifying mean? Where does it arise from? Why is being 'initially' 'conceived' in terms of what is objectively present, and not in terms of things at hand that do, after all, lie still nearer to us? Why does this reification come to dominate again and again? How is the being of 'consciousness' positively structured so that reification remains inappropriate to it? Is the 'distinction' between 'consciousness' and 'thing' sufficient at all for a primordial unfolding of the ontological problematic?"23 (Heidegger 2010, 414). Yet, as the Black Notebooks show, the contexts of the thing and of the process of turning the social into things (Verdinglichung, reification, thingification) are very different in Lukács and Heidegger's works. Like in Sein und Zeit, also the 1935/1936 lectures connect the critique of calculating reason with a critique of Descartes. Heidegger (1935/1936) makes clear that the question What is a Thing? is for him the question concerning technology: "on this [modern] physics are founded all our giant power stations, our airplanes, radio and television, the whole technology which has altered the earth and man with it more than he suspects. These are realities, not viewpoints which some investigators 'distant from life' defend. Does one want science even 'closer to life'? I think that it is already so close that it suffocates us. Rather, we need the right distance from life in order to attain a perspective in which we measure what is going on with us human beings. No one knows this today" (13-14). The longing for origin, pre-modernity, and moving

\footnotetext{
${ }^{22}$ Translation from German: „Weise der rechnenden Vergegenständlichung des Seienden“.

23 „Allein was bedeutet Verdinglichung? Woraus entspringt sie? Warum wird das Sein gerade "zunächst" aus dem Vorhandenen »begriffen « und nicht aus dem Zuhandenen, das doch noch näher liegt? Warum kommt diese Verdinglichung immer wieder zur Herrschaft? Wie ist das Sein des »Bewußtseins « positiv strukturiert, so daß Verdinglichung ihm unangemessen bleibt? Genügt überhaupt der »Unterschied « von »Bewußtsein« und »Ding" für eine ursprüngliche Aufrollung der ontologischen Problematik?” (Heidegger 1926, 576).
} 
away from technology is evident here and is another dimension that distinguishes Heidegger from Lukács.

In a passage titled Technology and Uprooting (Technik und Entwurzelung) Heidegger (2014a, 364 [Überlegungen V, §87]) expresses in the Black Notebooks his opposition to technology and argues that the "radio and all kinds of organisation [...] destroy"24 the village. He sees technology and organisation as "the opposite to all that is "organic"'25 (ibid.). The discussion of technology in the Black Notebooks shows that Heidegger considered the Nazis to be too modern in that they introduced modern technologies such as the radio that they used for ideological purposes. Heidegger seems to have had a pre-modern version of $\mathrm{Na}$ tional Socialism in mind. He leaves no doubt that he not only opposes the Nazis' table-top radio (Volksempfänger) that allowed the audience to just listen to one station controlled by Nazi propaganda, but all forms of the radio and modern communication technology.

Heidegger therefore writes: "From this essential context follows that »technology" can never be mastered by the völkisch-political worldview [the Nazi ideology]. What is already in essence a slave, can never become a master"26 (Heidegger 2014a, 472 [Ueberlegungen VI, 87]). He speaks of National Socialism that is influenced by journalism and culture as "vulgar National Socialism"27 (Heidegger 2014a, 142 [Überlegungen und Winke III, 81]), which makes once more clear that he hoped for the creation of a "spiritual National Socialism" 28 (Heidegger 2014a, 135 [Überlegungen und Winke III, §72]) without modern technology.

Heidegger's most important works on technology are the two essays The Question Concerning Technology and The Turning that go back to a series of lectures that he gave in the years 1949, 1950, and 1955 in Bremen and Munich. They were together published as the book Die Technik und die Kehre (Heidegger 1962) in German and The Question Concerning Technology and Other Essays (Heidegger 1977) in English.

When starting to talk about technology in The Question Concerning Technology, Heidegger $(1962,6)$ uses the term Zeug, which can be seen as a reference back to Sein und Zeit. For Heidegger, technology in essence is "a way of revealing" (Heidegger 1977, 12). It "has to do with the presencing [Anwesen] of that which at any given time comes to appearance in bringing-forth. Bringing-forth brings hither out of concealment forth into unconcealment" (11).

Heidegger $(1977,6)$ argues that Aristotle identified four important causes (causa materialis, cause formalis, causa finalis, causa efficiens), but modern technology is driven by the causa efficiens that is all about "means to obtain results, effects" (7). Modern technology would be a specific form of revealing, "a challenging [Herausfordern]" (14). Such challenging would challenge, i.e. dominate, nature and humans. It would therefore be "the monstrousness" [das Ungeheure] (16), the "danger" (26) and have "the character of a setting-upon" (16). Heidegger terms modern technology das Ge-stell (the Enframing), by which he means "that challenging claim which gathers man thither to order" (19). The Ge-stell is an instrumental form of revealing. "Enframing means the gathering together of that setting-upon which sets upon man, i.e., challenges him forth, to reveal the real, in the mode of ordering, as standing-reserve" (20). Modern technology as the Ge-stell would be associated with the exact sciences, mathematics, and modern physics (21) that have an instrumentalist worldview and believe in the calculability of the world.

The Ge-stell would result in the alienation of humans, man would have become "the order of the standing-reserve" [Besteller des Bestandes] (27). The Ge-stell endangers "man in his

\footnotetext{
${ }^{24}$ Translation from German: „Während Radio und allerlei Organisation das innere Wachsen und d.h. ständige Zurückwachsen in die Überlieferung im Dorf und damit dieses selbst zerstören, errichtet man Professuren für ,Soziologie' des Bauerntums und schreibt haufenweise Bücher über das Volkstum".

${ }^{25}$ Translation from German: „Die Technik und ihre Zwillingsschwester - die ,Organisation' - beide das Gegenläufige zu allem ,Organischen' - treiben ihrem Wesen nach auf ihr eigenes Ende, die Aushöhlung durch sich selbst,

${ }^{26}$ Translation from German: „Aus diesem Wesenszusammenhang ergibt sich, daß die »Technik« niemals durch die völkisch-politische Weltanschauung gemeistert werden kann. Was im Wesen schon Knecht ist, kann nie Herr werden“.

${ }^{27}$ Translation from German: „Vulgärnationalsozialismus”.

${ }^{28}$ Translation from German: "Geistiger Nationalsozialismus“
} 
relationship to himself and to everything that is" (27). Heidegger takes newspapers and illustrated magazines as one of the examples for the Ge-stell and says that they "set public opinion to swallowing what is printed, so that a set configuration of opinion becomes available on demand" (18).

The power of capitalism and the modern state, or what Habermas $(1984,1987)$ terms the systems of modern society that colonise the lifeworld, are absent both in Being and Time and The Question Concerning Technology, which is idiosyncratic given that modern society is based on the accumulation of capital and bureaucratic power, two structures that frame the development and use of modern technology. So a major problem of Heidegger's approach is that it is not a political economy, but merely a phenomenology of technology. He describes attributes of modern technology, such as instrumental logic, calculation, physics, the exact sciences, mathematics, in both books, but leaves open the question what the structural context of modern technology is. Heidegger's phenomenology in both books does not give an answer to the question what the causes of the problems he ascertains are. But he makes clear that the problem is not technology itself: "What is dangerous is not technology. There is no demonry of technology" (28). The danger would rather be the Ge-stell (28). The Ge-stell is however not an explanation in-itself, but an attribute of modern society. Heidegger neglects the analysis of capital and state power, two main features of modern society. So the two books leave open the question of the contexts of modernity's problems.

The Black Notebooks are, as we have seen in section 3, a work, in which Heidegger provided an answer to the question of the structural contexts of modernity and modern technology, as we have seen in section 3, the Black Notebooks, where he points out that the logic of calculability is Jewish. Heidegger identifies instrumental reason with Jews. So for him the cause and context of modernity and modern technology's problems - the rise of worldlessness and alienation - is seen in Jews.

There is a logical link between the Black Notebooks, Being and Time, and The Question Concerning Technology. The first provide the missing link and grounding for the second and the third. The Black Notebooks help explaining a theoretical void in the other two books. Das Man (the they) and das Ge-stell (the enframing) have in the Black Notebooks a grounding for Heidegger, namely what he and others term "world Jewry", i.e. the myth of a Jewish world conspiracy.

Only the full unshortened and uncensored publication of the Black Notebooks that Heidegger wrote after 1945 and public access to the Heidegger archive can show if the also wrote anti-Semitic philosophical notes after the Second World War ended and at the time when he wrote The Question Concerning Technology and later works ${ }^{29}$.

Heidegger also thought in The Question Concerning Technology about how humanity can be saved from the logic of modern technology. Technology could see "the possible arising of the saving power" (32). Heidegger associates such a salvation with "human reflection" (33), art as an alternative form of revealing, "the fine arts" (33), "poetry" (33), "everything poetical" (33), "the arrival of another destining" (39), "truth" (40), a focus on language and thinking (40), "the lightning-flash of the truth of Being" (45), "insight" (47)—what he all together calls the turning (die Kehre). Heidegger finally invokes the notion of the homeland in a mystical manner by asking: "Will we dwell as those at home in nearness, so that we will belong primarily within the fourfold of sky and earth, mortals and divinities?" (49). These thoughts are extremely abstract and idealist.

Heidegger imagines a new language and thinking that is at home in poetry as a form of rescue from modern technology. The only form of concreteness that Heidegger mentions when discussing the turning are poems by Hölderlin, Goethe, and Meister Eckehardt, from which he quotes. He exclusively alludes to non-Jewish German poets, which may be an indication that the turning and rescue also in The Question Concerning Technology remained what he in the Black Notebooks termed a spiritual National Socialism (see section 3). The

\footnotetext{
${ }^{29}$ See: http://www.hoheluft-magazin.de/2015/02/heidegger-enthuellung/ (accessed on March 1, 2015). Di Cesare, Donatella. Heidegger - "Jews Self-Destructed". New Black Notebooks Reveal Philosopher's Shocking Take on Shoah. Corriere della Sera, February 9, 2015. http://www.corriere.it/english/15 febbraio 09/heidegger-jews-selfdestructed-47cd3930-b03b-11e4-8615-d0fd07eabd28.shtml (accessed on March 1, 2015).
} 
new language he imagines is definitely German in character. Deutschtümelei (German jingoism) remained an element of Heidegger's philosophy of technology after 1945.

Tom Rockmore (1997, 241, 242-243) concludes his analysis of Heidegger's philosophy of technology by pointing out the role of Nazi ideology in it:

\begin{abstract}
Heidegger's failure to denounce, or even to acknowledge, Nazi practice can be interpreted as an oblique resistance to the practical consequences of his theoretical commitment. He was obviously unwilling to acknowledge the failure of his turn to Nazism, not for mere psychological reasons, but on good philosophical grounds; for his turn to Nazism was grounded in his own theory of Being, which he never abandoned. For the same reason, he was also unwilling to abandon National Socialism, or at least an ideal form of it, because of his continued interest in certain points where his thought converged with $\mathrm{Na}$ zism, including the coming to be of the Germans as German and the confrontation with technology. Heidegger's insensitivity to the effects of Nazism in practice is coupled, then, with a residual theoretical enthusiasm for a form of Nazism in theory. [...] Heidegger's supporters have suggested that Heidegger confronted Nazism through his theory of technology, or even that his theory of technology arises out of his confrontation with Nazism. Study of Heidegger's texts presents a different, darker picture of Heidegger, a thinker stubbornly committed to the metaphysical racism he shared with Nazism and to a revised version of the supposed Nazi effort to oppose technology. Heidegger's theory of technology is, then, not a confrontation with Nazism but a confrontation with technology from a Nazi perspective. Heidegger's theory of technology only extends, but does not free him from, his concern with National Socialism.
\end{abstract}

Rockmore (2007) also argues that Heidegger's philosophy of technology shares "the insistence on the authentic gathering of the Volk. Like his theory of Being, the theory of technology which derives from the theory of Being is intrinsically political, where politics is directed toward the authenticity of the Germans and beyond the Germans, toward knowledge of Being" (207).

Heidegger in a 1949 lecture in Bremen that focused on the Ge-stell, Heidegger's concept of modern technology, argued: "Agriculture is now a motorized (motorisierte) food industry, in essence the same as the manufacturing of corpses in the gas chambers and extermination camps, the same as the blockade and starvation of the countryside, the same as the production of the hydrogen bombs" ${ }^{30}$ (cited in: Farías 1989, 287). This talk was one of the events that prepared the publication of The Question Concerning Technology. In the published text, the quote was abridged: "Agriculture is now the mechanized food industry" (Heidegger 1977, 15).

Mahon O'Brien (2010) interprets this passage in a way that tries to turn Heidegger into a critical analyst of Nazism by arguing that he does not compare agricultural technologies to gas chambers because the formulation "in essence" would imply a more foundational level of analysis:

Heidegger believes that the motorized food industry, the Holocaust, the splitting of the atom, nuclear bombs, have as their common feature a technological backdrop. That is, regardless of the moral status of what happens or is done in each, they involve a technological way of revealing the world, or people or energy or animals. That is not to say that Heidegger is morally equating the consumption of animals with genocide. What he is saying, I would submit, is that the essence of technology, Gestell, holds sway as what is common in their approach to situations which we would never have conceived of in that way before. They indicate a mode of revealing the world or people or animals hitherto unimaginable. The fact that we were able to 'reveal' a people, in this instance 'The Jews', in such a way, might well be more morally repugnant than any of the other examples mentioned. But there is also something terribly sinister in looking for solutions to military problems through the unleashing of nature's stored up and harnessed power and thereby

\footnotetext{
${ }^{30}$ German original: „Ackerbau ist jetzt motorisierte Ernährungsindustrie, im Wesen das Selbe wie die Fabrikation von Leichen in Gaskammern und Vernichtungslagern, das Selbe wie die Blockade und Aushungerung von Ländern, das Selbe wie die Fabrikation von Wasserstoffbomben" (Heidegger 1994, 27).
} 
eradicating entire cities. The mass production of meat itself represents a change in the way we look at animals and their habitats. The point is that all of them have at their core a way of revealing the world which Heidegger is trying to call attention to. It is not a moral judgment to the effect that there are no qualitative differences. He is drawing attention to the fact that each of them involves a very specific and disturbing way of revealing" (O'Brien 2010, 13).

Gunkel and Taylor (2014, ix) make a comparable defensive argument: "It is critically important to note here that Heidegger is not saying that the mechanization of agriculture and the extermination camps are equivalent phenomena. Instead, the similarity being alluded to is one of essence, and it is this conceptualization that has profound implications for our understanding of media as an integral part of a diverse technological environment that shares certain essential features". They argue that Heidegger wants to point towards the "wider and more generalizable significance of the uniquely industrial nature of the Holocaust" (x).

Both O'Brien and Gunkel/Taylor try to defend Heidegger by setting up an implicit comparison to Horkheimer and Adorno's (2002) argument in the Dialectic of the Enlightenment that instrumental reason results in the Enlightenment's values turning against themselves so that forms of barbarism that enable Auschwitz emerge. Instrumental reason carried to the end enables Auschwitz, but such a development requires a political context, capitalism and fascism, about which Heidegger tends to be silent in his writings. Moishe Postone $(1980,2003)$ has built on Horkheimer and Adorno's argument and argues that Auschwitz was a negative factory, by which he means a factory for the annihilation of perceived enemies, absolute negativity.

National Socialism was the ultimate realisation of capitalism's fascist tendencies. It was a political project that tried to destroy Jews, the working class and its political representatives, and other groups with utmost violence, including forced labour and extermination camps. It was not simply an extension or the highest form of capitalism, of Fordism, or the capitalist factory system, but rather a negative factory for the extermination of Jews, political opponents, and others whom the Nazis considered as enemies. Moishe Postone describes this system the following way:

A capitalist factory is a place where value is produced, which 'unfortunately' has to take the form of the production of goods, of use-values. The concrete is produced as the necessary carrier of the abstract. The extermination camps were not a terrible version of such a factory but, rather, should be seen as its grotesque, Aryan, 'anticapitalist' negation. Auschwitz was a factory to 'destroy value', that is, to destroy the personifications of the abstract. Its organization was that of a fiendish industrial process, the aim of which was to 'liberate' the concrete from the abstract. The first step was to dehumanize, that is, to rip away the 'mask' of humanity, of qualitative specificity, and reveal the Jews for what 'they really are' - shadows, ciphers, numbered abstractions. The second step was to then eradicate that abstractness, to transform it into smoke, trying in the process to wrest away the last remnants of the concrete material 'use-value': clothes, gold, hair, soap (Postone 1980, 114).

The Nazis fully turned labour into a killing and extermination device. Forced labour forces had to work in the arms industry and other industries that were privately run and required workforces. Auschwitz and other extermination camps were to large degree negative factories-factories that aimed at the killing of Jews and other groups and individuals whom the Nazis considered as their enemies.

Heidegger only stresses the continuities of instrumental reason and disregards the contexts that make a qualitative difference, namely that Auschwitz does not produce use-values, but annihilate humans, which is captured by the category of the negative factory. This disregard and the context of Heidegger's own political history makes his remark so problematic. Neither O'Brien nor Gunkel/Taylor engage with the critical theory of anti-Semitism when discussing Heidegger's comment. The "care structure" of their arguments seems to be all about defending Heidegger against any criticism that argues that he was a Nazi and that his ideol- 
ogy was reflected in his work. One wonders if the publication of the Black Notebooks can challenges such beliefs in and defence of Heidegger or not. Emmanuel Faye $(2009,272)$ concludes about the passage in the Bremen lecture that it "tends to exonerate National Socialism from its radical responsibility in the annihilation of the Jewish people and the destruction of the human being to which the industry of Nazism was committed".

The Frankfurt School's works form a critique of instrumental reason, a critique of capitalism's reduction of humans to instruments whose labour serves capital accumulation, a critique of domination questioning the instrumentalisation of humans for fostering the rule and power of the few, and a critique of ideology questioning the instrumentalisation of human thinking. Frankfurt School critique of instrumental reason is however fundamentally different from Heidegger's analysis. Whereas Critical Theory's context is political economy, Heidegger's phenomenology is short-circuited and therefore prone to turn into an instrumental ideology itself. Stanley Aronowitz summarises the Frankfurt School's critique of instrumental reason in the introduction to a collection of Horkheimer's essays:

The bourgeoisie tolerated critical reason during its revolutionary rise to power against the restrictions imposed by feudal social relations. Once victorious, however, reason could only be tolerated in its quantitative forms - mathematics and science, which became instruments of bourgeois rule insofar as it required the expansion of capital to maintain its hegemony over society. In capitalist society, science was useful to the extent that it was trans- formed into industrial technique. But empiricism had gone too far. It left thought a slave to the given reality. The bourgeoisie systematically demythologized thought of its feudal inheritance, but it created new myths shrouded in the new absolutism of science. The two sides of bourgeois thought, positivism and metaphysics, are the unified world view of the bourgeoisie, split according to the prevailing division of labor between science, which serves industry, and religions and secular spiritual ideologies, which serve social domination" (in: Horkheimer 2002, XV).

Horkheimer for example explains the background of instrumental reason the following way:

Thus, in Europe, in the last decades before the outbreak of the present war, we find the chaotic growth of individual elements of social life: giant economic enterprises, crushing taxes, an enormous increase in armies and armaments, coercive discipline, one-sided cultivation of the natural sciences, and so on. Instead of rational organization of domestic and international relations, there was the rapid spread of certain portions of civilization at the expense of the whole. One stood against the other, and mankind as a whole was destroyed thereby. [...] In business life, the Fachgeist, the spirit of the specialist, knows only profit, in military life power, and even in science only success in a special discipline. When this spirit is left unchecked, it typifies an anarchic state of society (Horkheimer 2002, 266).

If one wants to ground a critique of modern technology and media, then approaches that are much better grounded in the analysis of society and political economy than Heidegger's phenomenology are available. Frankfurt School critique is one of them, although certainly not the only one.

\section{Conclusion}

I have in this article asked the question: What are and should be the implications of the publication of the Black Notebooks for the reception of Heidegger in the study, theory, and philosophy of media, communication, and technology?

The analysis showed that Heidegger's Black Notebooks use most of the elements of antiSemitism that Adorno identifies: Heidegger sees Jews and Germans as forming two races, identifies Jews with modernity, capitalism, and modern technology, makes use of mystical and naturalistic logic by arguing that Jews are uprooted and threaten the Germans' proclaimed rootedness, and considers Jews as a powerful "world Jewry" that rules the world as well as a homogenous collective to which he ascribes negative biological, social, and political 
characteristics. He ascribes to Jews a specific feature of capitalism, namely instrumental reason, by saying that they have a talent for calculation, and thereby conducts a National Socialist short-circuited critique of capitalism that ascribes capitalism and its ills to Jews.

Given that Heidegger identifies instrumental reason with Jews, his anti-Semitism has larger implications for his philosophy of technology and the media. There is a logical link between the Black Notebooks' anti-Semitism and the analysis of technology in Being and Time and The Question Concerning Technology. The first provide the missing link and grounding for the second and the third. The Black Notebooks help explaining a theoretical void in these other two books. Das Man (the they) and das Ge-stell (the enframing) have a grounding for Heidegger in the Black Notebooks, namely what he and others term "world Jewry", i.e. the myth of Jewish world conspiracy. Deutschtümelei (=German jingoism) remained an element of Heidegger's philosophy of technology after 1945.

What can and should the implications of the Black Notebooks' anti-Semitism and their grounding character for other of Heidegger's works be for the field of media and communication studies?

Heidegger's works have had a significant influence on contemporary media and communication studies, as evidenced by works that make him the or a central philosophical influence and focus on issues such as for example television and broadcasting (Scannell 2014, 1996), information ethics (Capurro 2003; Capurro, Eldred and Nagel 2013), the general philosophy of technology (Stiegler 1998, 2009, 2011; Ihde 2010), the theory of media and digital media (Gunkel and Taylor 2014), robotics and Artificial Intelligence (Gunkel 2012), the Internet (Dreyfus 2009), the philosophy of information (Borgmann 2000), digital culture (Miller 2012), digital media surveillance (Herzogenrath-Amelung 2013), digital media and transport (Herzogenrath-Amelung, Troullinou and Thomopoulos 2015), interaction studies (Dourish 2004), the philosophy of virtual reality (Heim 1993, 1998).

The works of these scholars tend to be interesting and critical. I do not see why they need Heidegger and cannot express the things they want to articulate without Heidegger and by making use of alternative, critical traditions. It rather seems to me that Heidegger fetishism is often l'art pour l'art, Heidegger pour Heidegger, a tactic that aims at creating an aura of complexity by evoking Heidegger although the same content could be expressed without him. Most of these scholars see themselves as political progressives. Often they are also vocal in voicing dissent with the opinion that Heidegger's philosophy is a form of Nazism. So for example Gunkel and Taylor argue that Heidegger's philosophy is a good way for critically understanding technology in Nazism and Nazi ideology:

There is nothing in Heidegger's philosophy that is innately fascistic. In fact, his critique of
technology explored in this book raises profound issues about technology's role in dehu-
manizing people, of which the Nazi death camps were the darkest historical manifesta-
tion. In this case, unalloyed censure of Heidegger's thought based upon his deeply
flawed political affiliation is not only an inadequate response - it misses an opportunity to
understand better the role technology played in facilitating Nazi ideology (Gunkel and
Taylor 2014 , viii).

At the same time, to my knowledge none of the mentioned scholars has thus far (until March 2015 when this article was published) commented publicly whether or not the anti-Semitism evidenced in the Black Notebooks that were published in spring 2014, has to lead to changes in the reception of Heidegger in media and communication studies. The judgement of Tom Rockmore $(1997,2)$ in his study On Heidegger's Nazism and Philosophy is also valid for the reception of the Black Notebooks: "To 'bracket' this issue, simply to turn away from the problem, to refuse to confront it, is silently to accept what a number have seen as the totalitarian dimension in one of the most important theories of this century". This non-reaction constitutes a strange asymmetry in the way Heideggerians deal with their philosophical guru's relationship to Nazism.

To be fair, one must say that one can and should not demand from those who are experts on Heidegger to understand German. One can be a perfect expert of a philosopher's works 
without having read the originals. To claim otherwise is a strange form of jingoism. Neither the Black Notebooks nor Peter Trawny's (2014) thoughtful analysis have been translated from German to English, which makes it difficult for scholars who do not read German to comment. Hopefully an English translation of Trawny's analysis will be available soon. In the meantime, also recordings of interesting English talks and discussions about the Black Notebooks involving Peter Trawny, Tom Rockmore, and others are available online: Peter Trawny's talks "Philosophy and Anti-Semitism: The Heidegger Case"31 and "Heidegger, 'World-Judaism', and Modernity" ${ }^{32}$, Tom Rockmore's talk "Heidegger's Anti-Semitism: Philosophy or Worldview?"33, the talks given at the 2014 conference "Heidegger's Black Notebooks: Philosophy, Politics, Anti-Semitism"34, a panel discussion with Emmanuel Faye, Jeffrey van Davis, Karsten Harries, Richard Wolin, and Thomas Sheehan ${ }^{35}$, or a panel discussion with Peter Trawny and Babette Babich ${ }^{36}$. Such materials allow and have allowed academics and others to form an opinion on the issue.

So my argument is that there are no good grounds for silence. A good example of a concrete reaction to the publication of the Black Notebooks is the anti-fascist practice of Günter Figal, professor of philosophy at the University of Freiburg, who in early 2015 stepped down from his position as president of the Heidegger Society. He argued that the Black Notebooks contain "anti-Semitic sentences" and that it would be difficult for him to "stand for a person, who has made such comments and who has made comments that I can only find detestable [abscheulich]"37 (translation from German). He says that the thinks the philosophical future is "the end of Heideggerianism" ${ }^{38}$ (translation from German).

Peter Trawny (2014), who is editor of the Black Notebooks and some other volumes of Heidegger's Collected Works as well as director of the University of Wuppertal's MartinHeidegger-Institute, argues that given that Heidegger's anti-Semitism was formulated in a philosophical context (120), that it is a fact that Heidegger wrote these philosophical comments at a time when Synagogues were burning in Germany (122), and that in them he formulated a lot of sorrow about what he considered to be the Germans' suffering but none about Jewish suffering (122), the Black Notebooks will result in a "crisis of the reception of his thought" (114) and require a "revision of the engagement with Heidegger's thinking" (117) [translation from German].

How can and will such an engagement with Heidegger's anti-Semitism look like and which form will it take in the field of media and communication studies, where Heidegger's general philosophy and his philosophy of technology have played an influential role? This article is my contribution and an attempt to start such a debate. My personal view is that the most appropriate reaction is that scholars distance themselves from Heidegger's works and stop giving prominence to them within media and communication studies (and other fields). It is time that Heideggerians abandon Heidegger and instead focus on alternative traditions of thought.

The French philosopher Emmanuel Faye $(2009,319)$ argues that Heidegger, "who has espoused the foundations of Nazism cannot be considered a philosopher" and that the "moment has come to resist the ill-advised opinion that Heidegger was a 'great philosopher'". The publication of the Black Notebooks has made this judgement even more topical. It is now also the moment where scholars should consider stopping to eulogise and reference Heidegger when theorising and analysing the media, communication, culture, technology, digital media, and the Internet.

\footnotetext{
${ }^{31}$ https://www.youtube.com/watch?v=LwNiMl1g9us, accessed on February 27, 2015.

32 https://www.youtube.com/watch?v=zzLMdQh9iTA, accessed on February 27, 2015.

33 https://www.youtube.com/watch?v=loj5dQr_IJk, accessed on February 27, 2015.

34 https://www.youtube.com/playlist?list=PLgEhVQ4kQGSpaE84Ha2Zec5t7b8c_8CKP, accessed on February 27 , 2015.

${ }^{35} \mathrm{https}: / /$ www.youtube.com/watch?v=hMizd8GpIEA, accessed on February 27, 2015.

36 https://vimeo.com/93782805, accessed on February 27, 2015.

37 "So denkt man nicht, wenn man Philosophie treibt". Günter Figal: Interview mit Radio Dreyeckland, January 9 , 2015, https://rdl.de/beitrag/so-denkt-man-nicht-wenn-man-philosophie-betreibt, accessed on March 1, 2015.

${ }^{38}$ German original: „Das Ende des Heideggerianertums“. In: Interview mit Günter Figal. Badische Zeitung, January 23,2015 . http://www.badische-zeitung.de/literatur-und-vortraege/das-ende-des-heideggerianertums, accessed on March 1, 2015.
} 


\section{References}

Adorno, Theodor W. 2002. Elements of anti-Semitism: Limits of Enlightenment. In Dialectic of Enlightenment: Philosophical Fragments, Max Horkheimer and Theodor W. Adorno, 137-172. Stanford, CA: Stanford University Press.

Adorno, Theodor W. 1965/2001. Metaphysics. Concept and Problems. Stanford, CA: Stanford University Press.

Adorno, Theodor W. 1960/1961. Ontologie und Dialektik. Frankfurt am Main: Suhrkamp.

Arendt, Hannah. 1958. The Origins of Totalitarianism. Orlando, FL: Harcourt Brace. New edition.

Borgmann, Albert. 2000. Holding on to Reality: The Nature of Information at the Turn of the Millennium. Chicago, IL: University of Chicago Press.

Capurro, Rafael. 2003. Ethik im Netz. Stuttgart: Franz Steiner Verlag.

Capurro, Rafael, Michael Eldred and Daniel Nagel. 2013. Digital Whoness: Identity, Privacy and Freedom in the Cyberworld. Frankfurt am Main: Ontos.

Cohen, Patricia. 2009. An Ethical Question: Does a Nazi Deserve a Place among Philosophers? New York Times Online, November 8, 2009. http://www.nytimes.com/2009/11/09/books/09philosophy.html

Dourish, Paul. 2001. Where the Action is: The Foundations of Embodied Interaction. Cambridge, MA: MIT Press.

Dreyfus, Hubert. 2009. On the Internet. Abingdon: Routledge. Second edition.

Farías, Victor . 1989. Heidegger and Nazism. Philadelphia, PA: Temple University Press.

Faye, Emmanuel. 2009. Heidegger: The Introduction of Nazism into Philosophy. New Haven, CT: Yale University Press.

Faye, Emmanuel 2005. Wie die Nazi-Ideologie in die Philosophie einzog. Die Zeit Online August 18, 2005. http://www.zeit.de/2005/34/AntwortHeidegger

Gunkel, David. 2012. The Machine Question: Critical Perspectives on Al, Robots, and Ethics. Cambridge, MA: MIT Press.

Gunkel, David and Paul A. Taylor. 2014. Heidegger and the media. Cambridge Polity.

Habermas, Jürgen. 1987. The Theory of Communicative Action. Volume 2. Boston, MA: Beacon Press.

Habermas, Jürgen. 1984. The Theory of Communicative Action. Volume 1. Boston, MA: Beacon Press.

Habermas, Jürgen. 1983. Der philosophische Diskurs der Moderne. Zwölf Vorlesungen. Frankfurt am Main: Suhrkamp.

Habermas, Jürgen. 1953. Martin Heidegger: On the Publication of the Lectures of 1935. In The Heidegger controversy, edited by Richard Wolin, 186-197. Cambridge, MA: MIT Press

Heidegger, Gertrud, ed. 2007. Mein liebes Seelchen! Briefe Martin Heideggers an seine Frau Elfride 1915-1970. München: btb.

Heidegger, Martin. 2014a. Gesamtausgabe, Band 94: Überlegungen II-VI (1931-1938). Frankfurt am Main: Klostermann.

Heidegger, Martin. 2014b. Gesamtausgabe, Band 95: Überlegungen VII-XI (1938/1939). Frankfurt am Main: Klostermann.

Heidegger, Martin. 2014c. Gesamtausgabe, Band 96: Überlegungen XII-XV (1939-1941). Frankfurt am Main: Klostermann.

Heidegger, Martin. 2010. Being and Time. Translated by Joan Stambaugh. Albany, NY: State University of New York Press. Revised edition.

Heidegger, Martin. 2001. Gesamtausgabe, Band 36/37: Sein und Wahrheit. Freiburger Vorlesungen Sommersemester 1933 und Wintersemester 1933/1934. Frankfurt am Main: Klostermann.

Heidegger, Martin. 2000. Introduction to Metaphysics. New Haven, CT: Yale University Press.

Heidegger, Martin. 1999. Contributions to Philosophy. Indianapolis, IN: Indiana University Press.

Heidegger, Martin. 1994. Gesamtausgabe, Band 79: Bremer und Freiburger Vorträge. Frankfurt am Main: Klostermann.

Heidegger, Martin. 1989. Gesamtausgabe, Band 65: Beiträge zur Philosophie. Frankfurt am Main: Klostermann.

Heidegger, Martin. 1983. Gesamtausgabe, Band 40: Einführung in die Metaphysik. Frankfurt am Main: Klostermann.

Heidegger, Martin. 1977. The Question Concerning Technology and Other Essays. New York: Harper. Heidegger, Martin. 1962. Die Technik und die Kehre. Stuttgart: Klett-Cotta. 
Heidegger, Martin. 1935/1936. What is a Thing? South Bend, IN: Gateway Editions.

Heidegger, Marin. 1929. Was ist Metaphysik? Frankfurt am Main: Klostermann. Siebente Auflage.

Heidegger, Martin. 1926. Sein und Zeit. Gesamtausgabe Band 2. Frankfurt am Main: Klostermann.

Heim, Michael. 1998. Virtual Realism. Oxford: Oxford University Press.

Heim, Michael. 1993. The Metaphysics of Virtual Reality. Oxford: Oxford University Press.

Herzogenrath-Amelung, Heidi. 2013. Ideology, Critique and Surveillance. tripleC 11 (2): 521-534.

Herzogenrath-Amelung, Heidi, Pinelopi Troullinou and Nikolas Thomopoulos. 2015. Reversing the order: Towards a Philosophically Informed Debate on ICT for Transport. In ICT for Transport: Opportunities and Threats, eds. Nikolas Thomopoulos, Moshe Givoni and Piet Rietveld. Cheltenham: Edward Elgar.

Horkheimer, Max. 2002. Critical theory. Selected essays. New York: Continuum.

Horkheimer, Max and Theodor W. Adorno. 2002. Dialectic of Enlightenment. Philosophical Fragments. Stanford, CA: Stanford University Press.

Ihde, Don. 2010. Heidegger's technologies: Postphenomenological Perspectives. New York: Fordham University Press.

Löwith, Karl. 1946. The Political Implications of Heidegger's Existentialism. In The Heidegger controversy, edited by Richard Wolin, 167-185. Cambridge, MA: MIT Press.

Lukács, Georg. 1923. History and Class Consciousness. Studies in Marxist Dialectics. Cambridge, MA: The MIT Press.

Meyer, Thomas. 2005. Denker für Hitler. Die Zeit Online July 21, 2005. http://www.zeit.de/2005/30/Heidegger

Miller, Vincent. 2012. A Crisis of Presence: On-line Culture and being in the World. Space and Polity 16 (3): 265-285.

O'Brien, Mahon. 2010. Re-assessing the 'Affair': the Heidegger Controversy Revisited. Social Science Journal 47 (1): 1-20.

Pöggeler, Otto. 1987. Martin Heidegger's Path of Thinking. Atlantic Highlands, NJ: Humanities Press International.

Postone, Moishe. 2003. The Holocaust and the trajectory of the twentieth century. In Catastrophe and Meaning. The Holocaust and the Twentieth Century, edited by Moishe Postone and Eric Santner, 81-114. Chicago, IL: University of Chicago Press.

Postone, Moishe. 1980. Anti-semitism and National Socialism: Notes on the German reaction to "Holocaust". New German Critique 19 (1): 97-115.

Rockmore, Tom. 2014. Heidegger's anti-Semitism: Philosophy or worldview? Contribution at the Conference Heidegger's Black Notebooks: Philosophy. Politics. Anti-Semitism. September 5-6, 2014. Emory University. Accessed on February 27, 2015. Audio recording: https://www.youtube.com/watch?v=loj5dQr_IJk.

Rockmore, Tom. 2009. Foreword to the English edition. In Heidegger: The Introduction of Nazism into Philosophy, Emmanuel Faye, vii-xxi New Haven, CT: Yale University Press.

Rockmore, Tom. 1997. On Heidegger's Nazism and philosophy. Berkeley, CA: University of California Press.

Rockmore, Tom and Joseph Margolis. 1989. Foreword. In Heidegger and Nazism, Victor Farías, ixxxi. Philadelphia, PA: Temple University Press.

Scannell, Paddy. 2014. Television and the Meaning of "Live": An enquiry into the human situation. Cambridge: Polity.

Scannell, Paddy. 1996. Radio, Television and Modern Life. Oxford: Blackwell.

Sieg, Ulrich. 1989. „Die Verjudung des deutschen Geistes“. Die Zeit, December 22, 1989. Accessed on February 27, 2015. http://www.zeit.de/1989/52/die-verjudung-des-deutschen-geistes.

Stiegler, Bernard. 2011. Technics and time 3: Cinematic Time and the Question of Malaise. Stanford, CA: Stanford University Press.

Stiegler, Bernard. 2009. Technics and Time 2: Disorientation. Stanford, CA: Stanford University Press.

Stiegler, Bernard. 1998. Technics and Time 1: The Fault of Epimetheus. Stanford, CA: Stanford University Press.

Trawny, Peter. 2014. Heidegger und der Mythos der jüdischen Weltverschwörung. Frankfurt am Main: Klostermann.

Vietta, Silvio. 1989. Heideggers Kritik am Nationalsozialismus und an der Technik. Tübingen: Max Niemeyer.

Wolin, Richard. 2014. National Socialism, World Jewry, and the History of Being: Heidegger's Black Notebooks. Jewish Review of Books Summer 2014, 
http://jewishreviewofbooks.com/articles/993/national-socialism-world-jewry-and-the-history-ofbeing-heideggers-black-notebooks/

Wolin, Richard, ed. 1993. The Heidegger controversy. Cambridge, MA: The MIT Press.

\section{About the Author}

\section{Christian Fuchs}

Christian Fuchs is a professor at the University of Westminster's Communication and Media Research Institute (CAMRI). He is editor of tripleC: Communication, Capitalism \& Critique. His research focuses on critical theory, political economy of media, communication, culture and the Internet, and critical media sociology. His monographs include Culture and Economy in the Age of Social Media (2015), OccupyMedia! The Occupy Movement and Social Media in Crisis Capitalism (2014), Digital Labour and Karl Marx (2014), Social Media: A Critical Introduction (2014), Foundations of Critical Media and Information Studies (2011), Internet and Society: Social Theory in the Information Age (2008). http://fuchs.uti.at, @fuchschristian. 